\title{
Relationship between physical activity related energy expenditure and body composition: a gender difference.
}

Citation for published version (APA):

Westerterp, K. R., \& Goran, M. (1997). Relationship between physical activity related energy expenditure and body composition: a gender difference. International Journal of Obesity, 21(3), 184-188. https://doi.org/10.1038/sj.ijo.0800385

Document status and date:

Published: 01/01/1997

DOI:

10.1038/sj.ijo.0800385

Document Version:

Publisher's PDF, also known as Version of record

\section{Document license:}

Taverne

Please check the document version of this publication:

- A submitted manuscript is the version of the article upon submission and before peer-review. There can be important differences between the submitted version and the official published version of record.

People interested in the research are advised to contact the author for the final version of the publication, or visit the DOI to the publisher's website.

- The final author version and the galley proof are versions of the publication after peer review.

- The final published version features the final layout of the paper including the volume, issue and page numbers.

Link to publication

\footnotetext{
General rights rights.

- You may freely distribute the URL identifying the publication in the public portal. please follow below link for the End User Agreement:

www.umlib.nl/taverne-license

Take down policy

If you believe that this document breaches copyright please contact us at:

repository@maastrichtuniversity.nl

providing details and we will investigate your claim.
}

Copyright and moral rights for the publications made accessible in the public portal are retained by the authors and/or other copyright owners and it is a condition of accessing publications that users recognise and abide by the legal requirements associated with these

- Users may download and print one copy of any publication from the public portal for the purpose of private study or research.

- You may not further distribute the material or use it for any profit-making activity or commercial gain

If the publication is distributed under the terms of Article $25 \mathrm{fa}$ of the Dutch Copyright Act, indicated by the "Taverne" license above, 


\title{
Relationship between physical activity related energy expenditure and body composition: a gender difference
}

\author{
KR Westerterp ${ }^{1}$ and MI Goran ${ }^{2}$ \\ ${ }^{1}$ Department of Human Biology, Maastricht University, Maastricht, The Netherlands and ${ }^{2}$ Energy Metabolism Research Unit, \\ Department of Nutrition Sciences, University of Albama at Birmingham, USA
}

\begin{abstract}
OBJECTIVE: The doubly labeled water method for the measurement of average daily metabolic rate (ADMR), combined with a measurement of basal metabolic rate (BMR), permits the calculation of energy expenditure for physical activity. Thus, the relation between physical activity and body composition (\%body fat) can be determined. METHOD: We analyzed existing data sets with observations on ADMR, BMR, and \%body fat including 290 healthy subjects, age 18-49y, 146 females and 144 males, from 22 different studies.

RESULTS: In a regression analysis, age explained 3-7\% and 5-20\% of the variation in \%body fat in females and males, respectively. Adding physical activity to the model raised the explained variation in \%body fat in males (partial $r=0.35, P<0.01$ ). A higher level of physical activity was related to a lower \%body fat. In females, there was no relationship between physical activity and body composition (partial $r=0.00, n$.s.).

CONCLUSION: In males, there is a significant inverse cross-sectional relationship between activity energy expenditure and percent body fat, whereas no such relationship was apparent in females.
\end{abstract}

Keywords: the doubly labeled water method; average daily metabolic rate; basal metabolic rate; physical activity; age; body composition

\section{Introduction}

Regular physical activity is suggested to be an important factor in the prevention of obesity. ${ }^{1}$ Population studies show a negative correlation between physical activity and degree of obesity but the correlation is typically quite low $(r=-0.12$ to -0.20$){ }^{2}$ Physical activity is the most variable component of daily energy expenditure and is difficult to quantify. ${ }^{3}$ The doubly labeled water method for the measurement of average daily metabolic rate (ADMR), combined with a measurement of basal metabolic rate (BMR), permits the calculation of energy expenditure for physical activity. Thus, the relation between physical activity and body composition (\%body fat) can be determined more reliably.

One of the first studies with doubly labeled water, comparing energy expenditure in lean and obese women, concluded that there was no evidence that obese subjects were less active than lean controls. ${ }^{4}$ Later studies, including females and males, confirmed that there were no significant differences between obese subjects and lean controls with respect to energy expenditure due to physical activity. ${ }^{5,6}$ One

Correspondence: Dr KR Westerterp, Department of Human Biology, Maastricht University, P.O. Box 616, 6200 MD Maastricht, The Netherlands.

Received 18 August 1996; revised 1 November 1996; accepted 11 November 1996 study in male Pima Indians concluded that obesity was associated with lower levels of physical activity. ${ }^{7}$ One of the limiting factors in the studies was the number of subjects being 10-32 for each gender separately.

Westerterp et $a l^{8}$ showed in a meta-analysis including 66 females and 30 males that in males a higher physical activity was related to a lower fat mass. Schulz and Schoeller ${ }^{9}$ analyzed data of 124 females and 68 males, showing that fatness increased with a lower energy expenditure for physical activity and again the relation was not as clear in women than in men. Black et $a l^{10}$ analyzed an even larger set of adults, 248 females and 163 males, showing no association between physical activity and weight. They did not include body fatness in the analysis. However, one of their main findings was the decrease of physical activity with increasing age, and age and body fatness are known to be correlated. Carpenter et $a l,{ }^{11}$ using weighted mean data of 162 adults of 13 studies, concluded that physical activity is not associated with adiposity. However, this paper did not examine gender differences in the relation of physical activity to body fat.

The aim of the present study is to analyze available data sets including ADMR, BMR, age, and body fatness of individual subjects to more thoroughly examine the relation between physical activity and body fatness, correcting for age. Physical activity is quantified by adjustment of ADMR for BMR as suggested by Carpenter et al. ${ }^{11}$ 


\section{Methods}

Existing data sets with observations on ADMR with doubly labeled water over at least one week, BMR, and \%body fat on individual subjects were included. BMR was measured with a ventilated hood or in a respiration chamber. \%Body fat was measured with hydrodensitometry or with isotope dilution. Exclusion criteria were age $<18$ and $>49 y$, non-Caucasian, an intervention in energy intake, an intervention in physical activity including athletic performance, pregnancy, lactation, and disease. Table 1 shows the studies included in the analysis with the number of subjects for each gender and a short description. The description includes information on the data selection in studies including an intervention. Generally, we selected the observations before an intervention.

Two hundred ninety healthy subjects, age $18-49 \mathrm{y}$, 146 females and 144 males, from 22 different studies were included. The heterogeneity of sources in the total sample of 22 different studies including different environmental (for example dietary) circumstances might have modulated any relationship between physical activity and \%body fat. Therefore in a subanalysis of a more homogeneous sample, studies were included with at least 10 subjects for each gender in a body mass range between 20 and $35 \mathrm{~kg} /$ $\mathrm{m}^{2}{ }^{21,27,30}$ Regression analysis was used to assess the contribution of age and physical activity as predictors for body fatness.

\section{Results}

Characteristics of the subjects are presented in Table 2 . The subjects cover a wide body-mass range, including anorectics with a minimal fat mass and morbid obese subjects with a massive fat mass. This resulted in an average \%body fat of 30 (range 5-58) in the females and 21 (range 3-60) in the males. The average physical activity level values $(\mathrm{PAL}=\mathrm{ADMR} /$ BMR) of 1.68 and 1.79 in the female and male groups, respectively, are close to the value for those engaged in moderate activity, and the range from $1.2-2.6$ in both groups covers the minimum to maintain life up to the level for somebody engaged in heavy work ${ }^{31,32}$ and represents the range for sustainable lifestyles. ${ }^{10}$

Using age and physical activity as predictors for \%body fat, we first analyzed the relationship between age and \%body fat. In both sexes, \%body fat increased significantly with increasing age (females: $r=0.26$, $P \leq 0.01$; males $r=0.22, P \leq 0.01$ (Table 3)). Including physical activity in the analysis raised the explained variation in \%body fat in males but not in females, males with a higher activity level having a lower \%body fat (partial $r$ : $0.35, P<0.001$ ) and in females no significant effect of physical activity on \%body fat (partial $r$ : 0.16, n.s.).

In the sub-sample (Table 4) \%body fat increased significantly with increasing age. However, in the smaller sample the relation was only significant for men (Table 5, Figure 1). Again, including physical activity in the analysis raised the explained variation in \%body fat in males as in the total sample (partial $r$ : $0.35, P<0.01$ ) and not in females (partial $r=0.00$. n.s.). In the sub-sample with a narrower/closer to normal range of \%body fat, the relation between \%body fat and physical activity was significantly different for women and men.

\section{Discussion}

The doubly labeled water method for the measurement of ADMR, combined with a measurement of BMR, is

Table 1 Studies included in the analysis

\begin{tabular}{|c|c|c|c|}
\hline \multirow[t]{2}{*}{ Authors and year } & \multicolumn{2}{|c|}{ Subject $n$} & \multirow[t]{2}{*}{ Description of the study } \\
\hline & Female & Male & \\
\hline Prentice et al 1986 & & 22 & Comparison obese-nonobese \\
\hline Westerterp et al 1988 & 1 & 4 & Follow-up of respiration chamber study \\
\hline Bandini et al 1989 & & 1 & Energy expenditure before overfeeding \\
\hline Bingham et al 1989 & 3 & 3 & Energy expenditure before exercise training \\
\hline Schulz et al 1989 & 2 & 4 & Comparison with heart rate measurements \\
\hline Caspar et al 1991 & 9 & & Energy expenditure and anorexia nervosa \\
\hline Goldberg et al 1991 & 10 & & Energy expenditure before pregancy \\
\hline Livingstone et al 1991 & 13 & 15 & Energy expenditure and leisure activity \\
\hline Roberts et al 1991 & & 13 & Energy expenditure in young adult men \\
\hline Westerterp et al 1991 & 3 & & Energy expenditure and sleeping metabolic rate \\
\hline Westerterp et al 1991 & 1 & 4 & Energy expenditure before gastroplasty \\
\hline Diaz et al 1992 & & 10 & Energy expenditure before overfeeding \\
\hline Meijer et al 1992 & 11 & 10 & Comparison obese-nonobese \\
\hline Schulz et al 1992 & 9 & & Energy expenditure in runners \\
\hline Westerterp et al 1992 & 5 & 8 & Energy expenditure before exercise training \\
\hline Goran et al 1993 & & 17 & Seasonal variation in energy expenditure \\
\hline Clark et al 1994 & 11 & & Energy expenditure in large- and small-eaters \\
\hline Haggarty et al 1994 & & 8 & Regular exercise and energy expenditure \\
\hline Pannemans et al 1995 & 10 & 19 & Energy expenditure in young adults \\
\hline Velthuis-te Wierik et al 1995 & & 8 & Energy expenditure before energy restriction \\
\hline Kempen et al 1996 & 19 & & Energy expenditure before dieting \\
\hline Westerterp et al 1996 & 17 & 20 & Energy expenditure and diet composition \\
\hline
\end{tabular}


Table 2 Characteristics of the subjects

\begin{tabular}{|c|c|c|c|c|c|c|}
\hline & \multicolumn{3}{|c|}{ Women $(n=146)$} & \multicolumn{3}{|c|}{$\operatorname{Men}(n=144)$} \\
\hline & Mean & s.d. & Range & Mean & s.d. & Range \\
\hline Age (y) & 31 & 7 & 19-48 & 30 & 8 & $18-49$ \\
\hline Height (m) & 1.65 & 0.06 & $1.47-1.81$ & 1.78 & 0.07 & $1.61-2.05$ \\
\hline Body mass $(\mathrm{kg})$ & 66 & 17 & $35-130$ & 78 & 20 & $56-216$ \\
\hline BMI $\left(\mathrm{kg} / \mathrm{m}^{2}\right)$ & 24.2 & 5.9 & $13.1-45.1$ & 24.4 & 5.4 & $17.7-61.7$ \\
\hline Body fat (\%) & 30 & 11 & $5-58$ & 21 & 8 & $3-60$ \\
\hline $\mathrm{BMR}(\mathrm{MJ} / \mathrm{d})$ & 6.0 & 0.9 & $3.2-9.6$ & 7.6 & 1.2 & $5.9-12.7$ \\
\hline $\operatorname{ADMR}(\mathrm{MJ} / \mathrm{d})$ & 10.0 & 2.2 & $5.1-15.3$ & 13.6 & 2.6 & $8.5-21.7$ \\
\hline ADMR/BMR & 1.67 & 0.27 & $1.15-2.57$ & 1.79 & 0.27 & $1.23-2.60$ \\
\hline
\end{tabular}

BMI, body mass index; BMR, basal metabolic rate; ADMR, average daily metabolic rate.

Table 3 Explained variance and regression coefficients $(\beta)$ of \%body fat on age and the residual of the ADMR/BMR relation

\begin{tabular}{lcccccc}
\hline & \multicolumn{2}{c}{ Women $(n=146)$} & & \multicolumn{2}{c}{ Men $(n=144)$} \\
\cline { 2 - 3 } \cline { 5 - 6 } & Variance (\%) & $\beta$ & & Variance (\%) & $\beta$ \\
\hline Age & 7 & $0.40^{*}$ & & 5 & $0.23^{*}$ \\
Residual of ADMR/BMR relation & 2 & -1.01 & & 13 & $-1.41^{* *}$ \\
Age and residual of ADMR/BMR relation & 10 & & & 17 &
\end{tabular}

*P<0.01; **P<0.001.

BMR, basal metabolic rate; ADMR, average daily metabolic rate.

Table 4 Characteristics of the subjects in the sub-sample of subjects from studies with at least 10 subjects for each gender in a body mass range between 20 and $35 \mathrm{~kg} / \mathrm{m}^{2}$

\begin{tabular}{|c|c|c|c|c|c|c|}
\hline & \multicolumn{3}{|c|}{ Women $(n=40)$} & \multicolumn{3}{|c|}{$\operatorname{Men}(n=54)$} \\
\hline & Mean & s.d. & Range & Mean & s.d. & Range \\
\hline Age (y) & 28 & 6 & $20-46$ & 30 & 6 & $19-46$ \\
\hline Height $(\mathrm{m})$ & 1.65 & 0.06 & $1.47-1.77$ & 1.80 & 0.06 & $1.67-1.93$ \\
\hline Body mass (kg) & 63 & 8 & $47-80$ & 78 & 10 & 60-111 \\
\hline BMI $\left(\mathrm{kg} / \mathrm{m}^{2}\right)$ & 23.3 & 2.8 & $18.3-30.0$ & 24.2 & 2.8 & $20.0-34.4$ \\
\hline Body fat (\%) & 30 & 7 & $18-42$ & 21 & 7 & 8-37 \\
\hline BMR (MJ/d) & 6.0 & 0.5 & $4.8-7.2$ & 7.7 & 0.9 & $6.1-9.7$ \\
\hline ADMR (MJ/d) & 10.4 & 1.3 & $7.5-12.6$ & 13.4 & 2.0 & $9.4-19.7$ \\
\hline ADMR/BMR & 1.73 & 0.17 & $1.38-2.09$ & 1.74 & 0.19 & $1.35-2.24$ \\
\hline
\end{tabular}

Table 5 Explained variance and regression coefficients $(\beta)$ of \%body fat on age and the residual of the ADMR/BMR relation in the sub-sample

\begin{tabular}{|c|c|c|c|c|}
\hline & \multicolumn{2}{|c|}{ Women $(n=40)$} & \multicolumn{2}{|c|}{$\operatorname{Men}(n=54)$} \\
\hline & Variance (\%) & $\beta$ & Variance (\%) & $\beta$ \\
\hline $\begin{array}{l}\text { Age } \\
\text { Residual of ADMR/BMR relation } \\
\text { Age and residual of ADMR/BMR relation }\end{array}$ & $\begin{array}{l}3 \\
0 \\
3\end{array}$ & $\begin{array}{r}0.18 \\
-0.02\end{array}$ & $\begin{array}{l}20 \\
15 \\
30\end{array}$ & $\begin{array}{r}0.29 * * \\
-1.33^{*}\end{array}$ \\
\hline
\end{tabular}

${ }^{*} P<0.01 ; * * P<0.001$.

$B M R$, basal metabolic rate; ADMR, average daily metabolic rate.

the gold standard for the assessment of physical activity related energy expenditure. The data presented in this study include current information extracted from the literature. We selected subjects in the age range 18$49 \mathrm{y}$, excluding subjects in their growth phase and the elderly. The elderly were excluded because of the discontinuous distribution of observations with respect to age. There are only few data on subjects aged 50 $60 \mathrm{y}$ while data in subjects aged over $60 \mathrm{y}$ are again readily available. The age distribution in the range 18 $49 \mathrm{y}$ was normal, for females as well as for males, allowing the regression analysis as presented.
\%Body fat was on average higher in females than in males, mean and range are as in the population as a whole. Females and males have a mean difference in \%body fat of about 10 after they have reached adult weight. The increase of \%body fat with age is due to a decrease in fat-free mass and an increase in fat mass. $^{33,34}$ The data of the total group $(n=290)$ did not show the phenomenon of a steeper increase of \%body fat with age in men than in women. ${ }^{35}$ However, the phenomenon was very pronounced in the subsample, excluding subjects with extreme underweight and overweight like anorectics and morbid obese. 


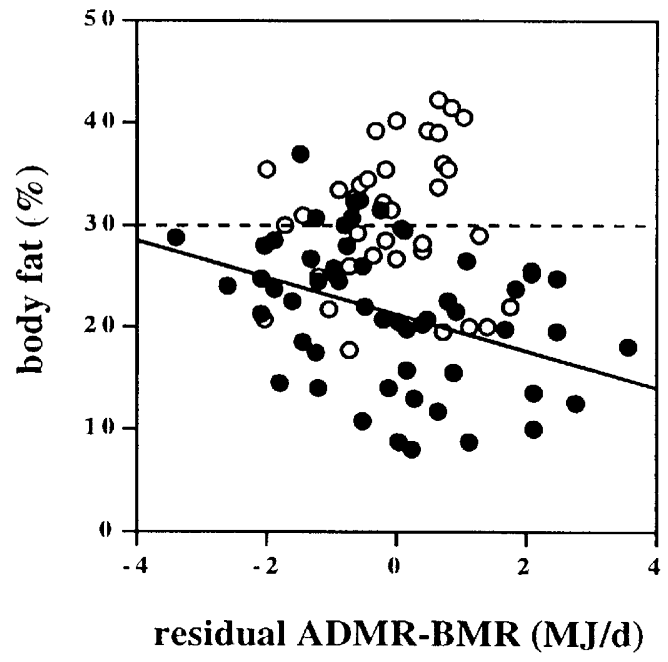

Figure $1 \%$ Body fat plotted as a function of physical activity expressed as the residual of the ADMR-BMR relation. This figure is data from the sub-sample of subjects from studies with at least 10 subjects for each gender in a body mass range between 20 and $35 \mathrm{~kg} / \mathrm{m}^{2}$. Solid circles are men, open circles are women. The graph shows the significant inverse relation in men (solid line) but not in women (dashed line).

There is no consensus on the way to quantify physical activity. We analyzed the data by adjustment of ADMR for BMR. An alternative way to quantify physical activity is by expressing ADMR as a multiple of BMR. ${ }^{32}$ It assumes that the variation in ADMR is due to body size and physical activity. The effect of body size on ADMR is corrected for by expressing ADMR as a multiple of BMR. Carpenter et $a l^{11}$ stated that the expression of ADMR as a multiple of BMR for comparison between subjects is precluded by the fact that the nature of the relation between ADMR and BMR is highly variable between studies and often has a nonzero intercept. They proposed to adjust ADMR for $\mathrm{BMR}$ to correct for the effect of body size in a linear regression analysis. Whatever of the two methods (ratio vs regression) was used to estimate physical activity, the result was the same. In males, a higher level of physical activity was related to a lower \%body fat. In females, there was no relationship between physical activity and body composition.

There has recently been some concern in relation to between-laboratory variability in the results of the doubly labeled water method for the measurement of ADMR ${ }^{36}$ In order to accommodate that data could be biased by study-specific circumstances, dummy variables for the origin of the data were included in all analyses. Conceptually, this means that differences within studies in body fatness were related to differences in age and physical activity within studies. The relations were not different, however, and the strength of the relations was pooled over studies.

Physical activity explained $12 \%$ of the variation in \%body fat in males. This estimate could be higher due to confounding and opposing effects of age on both physical activity (decreases with age) and body fat (increases with age). However, there was no significant relation between any of the activity estimates and age, not in females nor in males. The lack of a relation between age and physical activity in the data set selected was probably due to the limitation of the age range by selection of subjects age $18-49 \mathrm{y}$. In a simple regression the explained variation in \%body fat related to physical activity in males was 9-25\%, slightly but non-significantly higher than in the multiple regression with age and physical activity.

The explained variation of physical activity in \%body fat in the present analysis can be affected by an imprecision of the activity estimate ADMR adjusted for BMR. The error of measurement of ADMR and BMR separately results in a relatively large potential error in the combined activity estimate. The best test-retest precision for ADMR measurements with doubly labeled water is $8 \%$ and for BMR measurements 3\%. This might have diminished the calculated $r$ values. Additionally physical activity during the measured period of up to two weeks may not necessarily reflect the habitual level of physical activity over a longer period. Subjects may have decreased the activity level because they were not consuming their regular diet or may have increased their physical activity during the measurements because they were aware of the fact that physical activity related energy expenditure was measured. However, one of the advantages of the doubly labeled water technique is the unobtrusive nature of the measure. Subjects participating in doubly labeled water studies are usually unaware that activity is being measured.

The overall result, a gender difference of the relation between physical activity and body composition is consistent with findings from exercise-training studies. In exercise training studies, females tend to maintain fat stores whereas males are more likely to lose body fat in response to the same exercise challenge. The difference between the sexes is probably based on a difference in the ability to compensate for an increase in energy expenditure. Males tend to compensate less for an increase in energy expenditure by a change in energy intake when body fat stores permit. $^{23,37}$ Thus, exercise is not an effective modality to reduce body fat in females unless accompanied by restriction of energy intake. ${ }^{38}$ Other possible explanations for this gender dimorphism could be related to gender differences in body fat distribution. Males tend to have more abdominal fat than females, and abdominal fat has been shown to be more responsive to exercise interventions. ${ }^{39}$ The implication of the results is that females probably do not lose much fat when they adopt a higher level of physical activity. In males on the other hand, as expected, a higher level of physical activity is associated with a lower \%body fat.

\section{Conclusions}

In males, there is a significant inverse cross-sectional relationship between activity energy expenditure and 
percent body fat, whereas no such relationship was apparent in females.

\section{References}

1 Bouchard C, Deprés JP, Tremblay A. Exercise and obesity. Obes Res 1993; 1: 133-147.

2 Kromhout D, Saris WHM, Horst CH. Energy intake, energy expenditure and smoking in relation to body fatness: the Zutphen Study. Am J Clin Nutr 1988; 47: 668-674.

3 Meijer GAL, Westerterp KR, Verhoeven F, Koper H, ten Hoor F. Methods to assess physical activity with special reference to motion sensors and accelerometers. IEEE Trans Biomed Eng 1991; 38: 221-229.

4 Prentice AM, Black AE, Coward WA, Davies HL, Goldberg GR, Murgatroyd PR, Ashford J, Sawyer M, Whitehead RG. High levels of energy expenditure in obese women. $\mathrm{Br}$ Med $\mathrm{J}$ Clin Res Ed 1986; 292: 983-987.

5 Bandini LG, Schoeller DA, Dietz WH. Energy expenditure in obese and nonobese adolescents. Pediatr Res 1990; 27: 198 203.

6 Meijer GAL, Westerterp KR, van Hulsel AMP, ten Hoor F. Physical activity and energy expenditure in lean and obese adult human subjects. Eur J Appl Physiol 1992; 65: 525-528.

7 Rising R, Harper IT, Fontvielle AM, Ferraro RT, Spraul M, Ravussin E. Determinants of total daily energy expenditure: variability in physical activity. Am J Clin Nutr 1994; 59: 800804.

8 Westerterp KR, Meijer GAL, Kester ADM, Wouters L, ten Hoor F. Fat-free mass as a function of fat mass and habitual activity level. Int J Sports Med 1992; 13: 163-166.

9 Schulz LO, Schoeller DA. A compilation of total daily energy expenditures and body weights in healthy adults. $\mathrm{Am}$ $J$ Clin Nutr 1994; 60: 676-681.

10 Black AE, Coward WA, Cole TJ, Prentice AM. Human energy expenditure in affluent societies: an analysis of 574 doublylabelled water measurements. Eur J Clin Nutr 1996; 50: 72-92.

11 Carpenter WH, Poehlman ET, O'Connell M, Goran MI. Influence of body composition and resting metabolic rate on variation in total energy expenditure: a meta-analysis. $\mathrm{Am} \mathrm{J}$ Clin Nutr 1995; 61: 4-10.

12 Bandini LG, Schoeller DA, Edwards J, Young VR, Oh SH, Dietz WH. Energy expenditure during carbohydrate overfeeding in obese and nonobese adolescents. Am J Physiol 1989; 256: E357-E367.

13 Bingham SA, Goldberg GR, Coward WA, Prentice AM, Cummings JH. The effect of exercise and improved physical fitness on basal metabolic rate. Br J Nutr 1989; 61: 155-173.

14 Schulz S, Westerterp KR, Bruck K. Comparison of energy expenditure by the double labeled water technique with energy intake, heart rate and activity recording in man. Am J Clin Nutr 1989; 49: 1146-1154.

15 Casper RC, Schoeller DA, Kushner R, Hnilicka J, Gold ST. Total daily energy expenditure and activity level in anorexia nervosa. Am J Clin Nutr 1991; 53: 1143-1150.

16 Goldberg GR, Prentice AM, Coward WA, Davies HL, Murgatroyd PR, Sawyer MB, Ashford J, Black AE. Longitudinal assessment of the components of energy balance in wellnourished lactating women. Am J Clin Nutr 1991; 54: 788-798.

17 Livingstone MB, Strain JJ, Prentice AM, Coward WA, Nevin GB, Barker ME, Hickey RJ, McKenna PG, Whitehead RG. Potential contribution of leisure activity to the energy expenditure patterns of sedentary populations. Br J Nutr 1991; 65: 145-155.

18 Roberts SB, Heyman MB, Evans WJ, Fuss P, Tsay R, Young VR. Dietary energy requirements of young adult men, determined by using the doubly labeled water method. Am J Clin Nutr 1991; 54: 499-505.
19 Westerterp KR, Meijer GA, Saris WH, Soeters PB, Winants Y, ten Hoor F. Physical activity and sleeping metabolic rate. Med Sci Sports Exer 1991; 23: 166-170.

20 Westerterp KR, Saris WHM, Soeters PB, ten Hoor F. Determinants of weight loss after vertical banded gastroplasty. Int $J$ Obes 1991; 15: 529-534.

21 Diaz EO, Prentice AM, Goldberg GR, Murgatroyd PR, Coward WA. Metabolic response to experimental overfeeding in lean and overweight healthy volunteers. Am J Clin Nutr 1992; 56: 641-655.

22 Schulz LO, Alger S, Harper I, Wilmore JH, Ravussin E. Energy expenditure of elite female runners measured by respiratory chamber and doubly labeled water. $J$ Appl Physiol 1992; 72: 23-28.

23 Westerterp KR, Meijer GAL, Janssen EME, Saris WHN, ten Hoor F. Long term effect of physical activity on energy balance and body composition. Br J Nutr 1992; 68: 21-30.

24 Goran MI, Beer WH, Wolfe RR, Poehlman ET, Young VR. Variation in total energy expenditure in young healthy freeliving men. Metabolism 1993; 42: 487-496.

25 Clark D, Tomas F, Withers RT, Chandler C, Brinkman M, Phillips J, Berry M, Ballard FJ, Nestel P. Energy metabolism in free-living, 'large-eating' and 'small-eating' women: studies using ${ }^{2} \mathrm{H}_{2}{ }^{18} \mathrm{O}$. Br J Nutr 1994; 72: 21-31.

26 Haggarty P, McNeill G, Abu Manneh MK, Davidson L, Milne E, Duncan G, Ashton J. The influence of exercise on the energy requirements of adult males in the UK. Br J Nutr 1994; 72: 799-813.

27 Pannemans DLE, Westerterp KR. Energy requirements of the elderly. Br J Nutr 1995; 73: 571-581.

28 Velthuis-te Wierik EJM, Westerterp KR, van den Berg H. Impact of a moderately energy-restricted diet on energy metabolism and body composition in non-obese men. Int $J$ Obes 1995; 19: 318-324.

29 Kempen KPG, Saris WHM, Westerterp KR. Energy balance during 8 weeks energy-restrictive diet with and without exercise in obese females. Am J Clin Nutr 1995; 62: 722-729.

30 Westerterp KR, Verboeket-van de Venne WPHG, Bouten CVC, de Graaf C, van het Hof KH, Weststrate JA. Energy expenditure and physical activity in subjects consuming full- or reduced-fat diets. Br J Nutr 1996; 76: 785-795.

31 Waterlow JC. Notes on the new international estimates of energy requirements. Proc Nutr Soc 1986; 45: 351-360.

32 World Health Organization. Energy and protein requirements, report of a joint $\mathrm{FAO} / \mathrm{WHO} / \mathrm{UNU}$ expert consultation. Technical Report Series 724, Geneva 1985.

33 Forbes GB, Reina JC. Adult lean body mass declines with age: some longitudinal observations. Metabolism 1970; 19: 653-663.

34 Westerterp KR, Donkers JHHLM, Fredrix EWHM, Boekhoudt P. Energy intake, physical activity and body weight: a simulation model. Br J Nutr 1995; 73: 337-347.

35 Westerterp KR, Verboeket-van de Venne WPHG, WesterterpPlantenga MS, Velthuis-te Wierik EJM, de Graaf C, Weststrate JA. Dietary fat and body fat: an intervention study. Int $J$ Obes 1996; 20: 1022-1026.

36 Roberts SB, Dietz W, Sharp T, Dallal GE, Hill JO. Multiple laboratory comparison of the doubly labeled water technique. Obes Res 1995; 3(S1): 3-14.

37 Tremblay A, Després JP, Leblanc C, Bouchard C. Sex dimorphism in fat loss in response to exercise-training. $J$ Obes Weight Regul 1984; 3: 193-203.

38 Gleim GW. Exercise is not an effective weight loss modality in women. J Am Coll Nutr 1993; 12: 363-367.

39 Egger G, O'Neill M, Bolton A, Freeman D. Results of an abdominal obesity reduction program for men only: the gutbuster 'waist' loss program. Int J Clin Obes 1995; 19(S2): 37. 